\title{
Increasing Sigma levels in productivity improvement and industrial sustainability with Six Sigma methods in manufacturing industry: A systematic literature review
}

\author{
Purba, H.H. ${ }^{a}$, Nindiani, A. ${ }^{\text {b, }}{ }^{,}$, Trimarjoko, A. ${ }^{a}$, Jaqin, C. ${ }^{a}$, Hasibuan, S. ${ }^{a}$, Tampubolon, S. ${ }^{a}$ \\ aDepartment of Industrial Engineering, Mercu Buana University, Jakarta, Indonesia \\ bIndustrial Engineering Program, Buana Perjuangan University, Karawang, Indonesia
}

\begin{abstract}
A B S T R A C T
Industrial sustainability is an important attribute and becomes a parameter of the business success. Quality improvement with an indicator of increasing process capability will affect productivity improvements and lead to industrial competitiveness and maintain industrial sustainability. The purpose of this paper is to obtain a relationship between the consistency of the DMAIC phase to increase the sigma level in productivity improvement and industrial sustainability. This paper applied for a systematic literature review from various sources of trusted articles from 2006 to 2019 using the keywords "Six Sigma, Productivity, and Industrial Sustainability." A matrix was developed to provide synthesis and summary of the literature. Six Sigma approach has been successful in reducing product variation, defects, cycle time, production costs, as well as increasing customer satisfaction, cost savings, profits, and competitiveness to maintain industrial sustainability. Extraction and synthesis in this study managed to obtain seven objectives value that found a consistent relationship between the DMAIC phase of increasing sigma levels, productivity, and industrial sustainability. The broad scope of Six Sigma literature is very beneficial for organizations to understand the critical variables and key success factors in Six Sigma implementation, which leads to substantial long-term continuous improvement, the value of money, and business.
\end{abstract}

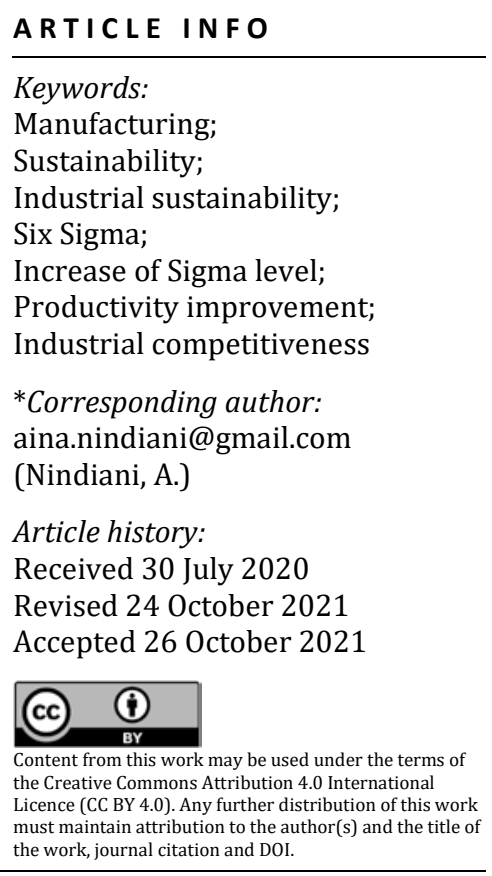

\section{ARTICLE INFO}

Keywords

Manufacturing;

Sustainability

Industrial sustainability

Sigma;

Increase of Sigma

Productivity improvement;

*Corresponding author:

aina.nindiani@gmail.com

Revised 24 October 2021

Accepted 26 October 2021

\section{References}

[1] Raman, R.S., Basavaraj, Y. (2019). Defect reduction in a capacitor manufacturing process through six sigma concept: A case study, Management Science Letters, Vol. 9, 253-260, doi: 10.5267/j.msl.2018.11.014.

[2] Tsoukatos, E., Rand, G.K. (2006). Path analysis of perceived service quality, satisfaction and loyalty in Greek insurance, Managing Service Quality: An International Journal, Vol. 16, No. 5, 501-519, doi: 10.1108/09604520 610686746.

[3] John, J. (2011). An analysis on the customer loyalty in telecom sector: Special reference to Bharath Sanchar Nigam limited, India, African Journal of Marketing Management, Vol. 3, No. 1, 1-5.

[4] Loke, S.-P., Taiwo, A.A., Salim, H.M., Downe, A.G. (2011), Service quality and customer satisfaction in a telecommunication service provider, In: Proceedings of 2011 International Conference on Financial Management and Economics, Singapore, 23-29.

[5] Khawale, Y.S., Jagdale, S.C., Jambhalekar, S.S., Kale, S.S., Patil, V.H. (2017). Implementation of six sigma methodology for piston rod manufacturing, Global Research and Development Journal for Engineering, Vol. 2, No. 3, 14-18.

[6] Hadi, H.A., Purba, H.H., Indarto, K.S., Simarmata, R.G.P., Putra, G.P., Ghazali, G., Aisyah, S. (2017) The implementation of quality function deployment (QFD) in tire industry, ComTech, Vol. 8, No. 4, 223-228, doi: 10.21512/comtech.v8i4.3792. 
[7] Maheshwari, M., Taparia, P. (2019). Measurement of material productivity: A case study of pharmaceutical sector companies included in Nifty 50, Productivity, Vol. 60, No. 2, 175-194, doi: 10.32381/PROD.2019.60.02.7.

[8] Thorelli, H.B. (1960). The tantalizing concept of productivity, American Behavioral Scientist, Vol. 4, No. 3, 6-11, doi: $10.1177 / 000276426000400303$.

[9] Levesque, T., McDougall, G.H.G. (1996). Determinants of customer satisfaction retail banking, International Journal of Bank Marketing, Vol. 14, No. 7, 12-20, doi: 10.1108/02652329610151340.

[10] Srivastava, S., Bhatnagar, A. (2013). Impact of customer care services on customer satisfaction - A study of mobile phone subscribers of u.p. (east) circle, International Journal of Management Research and Review, Vol. 3, No. 1, 2224-2242.

[11] Otim, S., Grover, V. (2006). An empirical study on web-based services and customer loyalty, European Journal of Information Systems, Vol. 15, No. 6, 527-541, doi: 10.1057/palgrave.ejis.3000652.

[12] Chang, H.H., Wang, H.-W. (2011). The moderating effect of customer perceived value on online shopping behaviour, Online Information Review, Vol. 35, No. 3, 333-359, doi: 10.1108/14684521111151414.

[13] Parasuraman, A., Grewal, D. (2000). The impact of technology on the quality-value-loyalty chain: A research agenda, Journal of the Academy of Marketing Science, Vol. 28, No. 1, 168-174, doi: 10.1177/0092070300281015.

[14] Kheng, L.L., Mahamad, O., Ramayah, T., Mosahab, R. (2010). The impact of service quality on customer loyalty: A study of banks in Penang, Malaysia, International Journal of Marketing Studies, Vol. 2, No. 2, 57-66, doi: 10.5539/ijms.v2n2p57.

[15] John, B., Areshankar, A. (2018). Reduction of rework in bearing end plate using six sigma methodology: A case study, Journal of Applied Research on Industrial Engineering, Vol. 5, No. 1, 10-26, doi: 10.22105/jarie.2018. 120059.1033.

[16] Anand, R.B., Shukla, S.K., Ghorpade, A., Tiwari, M.K., Shankar, R. (2007). Six sigma-based approach to optimize deep-drawing operation variables, International Journal of Production Research, Vol. 45, No. 10, 2365-2385, doi: $10.1080 / 00207540600702308$.

[17] Rahman, A., Shaju, S.U.C., Sarkar, S.K., Hashem, M.Z., Hasan, S.M.K., Islam, U. (2018). Application of six sigma using define measure analyze improve control (DMAIC) methodology in garment sector, Independent Journal of Management \& Production, Vol. 9, No. 3, 810-826, doi: 10.14807/ijmp.v9i3.732.

[18] Barbosa, B., Pereira, M.T., Silva, F.J.G., Campilho, R.D.S.G. (2017). Solving quality problems in tyre production preparation process: A practical approach, Procedia Manufacturing, Vol. 11, 1239-1246, doi: 10.1016/i.promfg. 2017.07.250.

[19] Rana, P., Kaushik, P. (2018). Initiatives of six-sigma in an automotive ancillary unit: A case study, Management Science Letters, Vol. 8, 569-580, doi: 10.5267/j.msl.2018.4.033.

[20] Hassan, M.K. (2013). Applying lean six sigma for waste reduction in a manufacturing environment, American Journal of Industrial Engineering, Vol. 1, No. 2, 28-35.

[21] Sławik, D., Czop, P., Król, A., Wszołek, G. (2010). Optimization of hydraulic dampers with the use of design for six sigma methodology, Journal of Achievements in Materials and Manufacturing Engineering, Vol. 43, No. 2, 676-683.

[22] Gerger, A., Firuzan, A.R. (2016). Use of six sigma method as a process improvement technique: A case study in aerospace industry, Academic Journal of Science, Vol. 6, No. 1, 191-202.

[23] Kosieradzka, A., Ciechańska, 0. (2018). Impact of enterprise maturity on the implementation of six sigma concept, Management and Production Engineering Review, Vol. 9, No. 3, 59-70, doi: 10.24425/119535.

[24] Sardeshpande, A.K., Khairnar, H.P. (2014). Application of six sigma in four wheeler platform truck with quality tools and techniques, International Journal of Engineering Development and Research, Vol. 2, No. 1, 126-134.

[25] Ganguly, K. (2012). Improvement process for rolling mill through the DMAIC six sigma approach, International Journal for Quality Research, Vol. 6, No. 3, 221-231.

[26] Syafwiratama, O., Hamsal, H., Purba, H.H. (2017). Reducing the nonconforming products by using the six sigma method: A case study of a polyester short cut fiber manufacturing in Indonesia, Management Science Letters, Vol. 7, 153-162, doi: 10.5267/i.msl.2016.12.001.

[27] Malek, J., Desai, D. (2015). Reducing rejection/rework in pressure die casting process by application of DMAIC methodology of six sigma, International Journal for Quality Research, Vol. 9, No. 4, 577-604.

[28] Gandhi, S.K., Sachdeva, A., Gupta, A. (2019). Reduction of rejection of cylinder blocks in a casting unit: A six sigma DMAIC perspective, Journal of Project Management, Vol. 4, 81-96, doi: 10.5267/i.jpm.2019.1.002.

[29] Chabukswar, A.R., Jagdale, S.C., Kuchekar, B.S., Kothawade, H.S., Kuckekar, A.B., Joshi, V.D., Deshmukh, G.R., Lokhande, P.D. (2011). Six sigma: Process of understanding the control and capability of ranitidine hydrochloride tablet, Journal of Young Pharmacists, Vol. 3, No. 1, 15-25, doi: 10.4103/0975-1483.76415.

[30] Noriega Morales, S., Valles Ch., A., Torres-Argüelles, V., Martínez, G.E. Hernández, G.A. (2016). Six sigma improvement project in a concrete block plant, Construction Innovation, Vol. 16, No. 4, 526-544, doi: 10.1108/CI01-2015-0003.

[31] Chang, K.K., Wang, F.K. (2008). Applying six sigma methodology to collaborative forecasting, The International Journal of Advanced Manufacturing Technology, Vol. 39, 1033-1044, doi: 10.1007/s00170-007-1276-5.

[32] Rahman, M.A., Talapatra, S. (2015). Defects reduction in casting process by applying six sigma principles and DMAIC problem solving methodology (A case study), In: Proceedings of International Conference on Mechanical, Industrial and Materials Engineering 2015 (ICMIME2015), Rajshahi, Bangladesh, 1-6.

[33] Srinivasan, K., Muthu, S., Devadasan, S.R., Sugumaran, C. (2016). Enhancement of sigma level in the manufacturing of furnace nozzle through DMAIC approach of six sigma: A case study, Production Planning \& Control, Vol. 27, No. 10, 810-822, doi: 10.1080/09537287.2016.1143130.

[34] Adeyemi, Y., Needy, K.L. (2006). An analysis of six sigma at small vs. large manufacturing companies, In: Proceedings of IIE Annual Conference, Norcross, USA, 1-6.

[35] Pyzdek, T. (2003). The six sigma handbook, Mc Graw Hill, New York, USA. 
[36] Hussain, T., Jamshaid, H., Sohail, A. (2014). Reducing defects in textile weaving by applying six sigma methodology: A case study, International Journal of Six Sigma and Competitive Advantage, Vol. 8, No. 2, 95-104, doi: 10.1504/IJSSCA.2014.064254.

[37] Purba, H.H., Aisyah, S. (2017). Quality improvement and lean six sigma: Meningkatkan kulitas produk dan kinerja perusahaan menuju zero defect, Expert, Yogyakarta, Indonesia.

[38] Ryall, J., Krunithof, J. (2001). The quality systems handbook, Consesus Books, Sydney, Australia.

[39] Gupta, V., Jain, R., Meena, M.L., Dangayach, G.S. (2018). Six-sigma application in tire-manufacturing company: A case study, Journal of Industrial Engineering International, Vol. 14, No. 3, 511-520, doi: 10.1007/s40092-017$\underline{0234-6 .}$

[40] Primanintyo, B., Syafei, Y.M., Luviyanti, D. (2016). Analisis penurunan jumlah defect dalam proses tire-curing dengan penerapan konsep six sigma, Journal of Industrial Engineering, Vol. 1, No. 2, Bekasi, Indonesia.

[41] Zasadzień, M. (2017). Application of the six sigma method for improving maintenance processes - Case study, In: Proceedings of the $6^{\text {th }}$ International Conference on Operations Research and Enterprise Systems (ICORES 2017), Porto, Portugal, 314-320, doi: 10.5220/0006184703140320.

[42] KPMG. (2015). The KPMG survey of corporate responsibility reporting 2015, Switzerland, KPMG International.

[43] Chaka, M. (2018). Sustainability reporting in South Africa: A descriptive and comparative analysis, Journal of Gender, Information and Development in Africa, Vol. 7, No. 2, 159-184, doi: 10.31920/2050-4284/2018/v7n2a8.

[44] Grewal, J., Serafeim, G., Yoon, A. (2016). Shareholder activism on sustainability issues, Harvard Business School Working paper, No. 17-003, doi: 10.2139/ssrn.2805512.

[45] Nugroho, D.M. (2015). Pengaruh kualitas pelayanan, kualitas produk layanan, dan harga produk layanan terhadap kepuasan pelanggan serta dampaknya terhadap loyalitas pelanggan prabayar telkomsel, Jurnal Operations Excellence: Journal of Applied Industrial Engineering, Vol. 7, No. 2, 158-174.

[46] Colwell, S., Hogarth-Scott, S., Jiang, D., Joshi, A. (2009). Effects of organizational and serviceperson orientation on customer loyalty, Management Decision, Vol. 47, No. 10, 1489-1513, doi: 10.1108/00251740911004655.

[47] Marakanon, L., Panjakajornsak, V. (2017). Perceived quality, perceived risk and customer trust affecting customer loyalty of environmentally friendly electronics products, Kasetsart Journal of Social Sciences, Vol. 38, No. 1, 24-30, doi: 10.1016/j.kjss.2016.08.012.

[48] Kitchenham, B., Charters, S. (2007). Guidelines for performing systematic literature reviews in software engineering (EBSE 2007-001), Technical report, Keele University and Durham University Joint Report.

[49] Bolderston, A. (2008). Writing an effective literature review, Journal of Medical Imaging and Radiation Sciences, Vol. 39, No. 2, 86-92, doi: 10.1016/j.jmir.2008.04.009.

[50] Kumar, C.S.C., Naidu, N.V.R. (2012). Minimizing the eighth waste of lean-absenteeism through six sigma methodology, International Journal for Quality Research, Vol. 6, No. 2, 113-118.

[51] Naidu, N.V.R. (2011). Development of mathematical models for optimal preventive maintenance policy in a steel industry: Six sigma approach, International Journal for Quality research, Vol. 5, No. 3, 179-185.

[52] Zhan, W. (2008). A six sigma approach for the robust design of motor speed control using modelling and simulation, International Journal of Six Sigma and Competitive Advantage, Vol. 4, No. 2, 95-113, doi: 10.1504/ IJSSCA.2008.020277.

[53] Gajbhiye, P.R., Waghmare, A.C., Parikh, R.H. (2016). Applications of lean six sigma methodologies for improvement in industrial safety, International Journal for Innovative Research in Science \& Technology, Vol. 3, No. 6, 168-175.

[54] Chang, S.-I., Yen, D.C., Chou, C.-C., Wu, H.-C., Lee, H.-P. (2012). Applying six sigma to the management and improvement of production planning procedure's performance, Total Quality Management \& Business Excellence, Vol. 23, No. 3-4, 291-308, doi: 10.1080/14783363.2012.657387.

[55] Purnama, G.N.T., Gunanto, Sugengriadir, R.M. (2019). Increasing the implementation of environmental management systems based ISO 14001 with the six sigma: Case study method in a manufacturing industry, International Journal of Research in Engineering, Science and Management, Vol. 2, No. 1, 103-106.

[56] El Hassani, I., Benlaajili, S., Nokra, N. (2017). Optimization of the particle size distribution of white sugar using six sigma methodology, International Journal of Advance Engineering and Research Development, Vol. 4, No. 9, 190-204, doi: 10.21090/IJAERD.71557.

[57] Soković, M., Pavletić, D., Krulčić, E. (2006). Six sigma process improvements in automotive parts production, Journal of Achievements in Materials and Manufacturing Engineering, Vol. 19, No. 1, 96-102.

[58] Rathilall, R., Singh, S. (2018). A lean six sigma framework to enhance the competitiveness in selected automotive component manufacturing organisations, South African Journal of Economic and Management Sciences, Vol. 21, No. 1, 1-13, doi: $10.4102 /$ sajems.v21i1.1852.

[59] Kaushik, P., Khanduja, D. (2007). DM make up water reduction in thermal power plants using six sigma DMAIC methodology, Journal of Scientific \& Industrial Research, Vol. 67, 36-42.

[60] Desai, D., Prajapati, B.N. (2017). Competitive advantage through Six Sigma at plastic injection molded parts manufacturing unit: A case study, International Journal of Lean Six Sigma, Vol. 8, No. 4, 411-435, doi: 10.1108/IJLSS06-2016-0022.

[61] Gijo, E.V., Scaria, J., Antony, J. (2011). Application of six sigma methodology to reduce defects of a grinding process, Quality and Reliability Engineering International, Vol. 27, No. 8, 1221-1234, doi: 10.1002/qre.1212.

[62] Anderson, N.C., Kovach, J.V. (2014). Reducing welding defects in turnaround projects: A lean six sigma case study, Quality Engineering, Vol. 26, No. 2, 168-181, doi: 10.1080/08982112.2013.801492.

[63] Sharma, P., Malik, S.C., Gupta, A., Jha, P.C. (2018). A DMAIC six sigma approach to quality improvement in the anodizing stage of the amplifier production process, International Journal of Quality \& Reliability Management, Vol. 35, No. 9, 1868-1880, doi: 10.1108/IJQRM-08-2017-0155. 
[64] Kumaradivel, A., Natarajan, U. (2013). Application of six sigma DMAIC methodology to sand-casting process with response surface methodology, The International Journal of Advanced Manufacturing Technology, Vol. 69, 14031420, doi: $10.1007 / \mathrm{s} 00170-013-5119-2$.

[65] Lo, W.C., Tsai, K.M., Hsieh, C.Y. (2009). Six sigma approach to improve surface precision of optical lenses in the injection-molding process, The International Journal of Advanced Manufacturing Technology, Vol. 41, 885-896, doi: $10.1007 / \mathrm{s} 00170-008-1543-0$.

[66] Chen, J.C., Li, Y., Cox, R.A. (2009). Taguchi-based six sigma approach to optimize plasma cutting process: An industrial case study, The International Journal of Advanced Manufacturing Technology, Vol. 41, 760-769, doi: 10.1007/s00170-008-1526-1.

[67] Jacob, J.J., Jenson J.E. (2014). Reducing the throughput time by value stream mapping in a tyre manufacturing industry, International Journal of Engineering Research \& Technology, Vol. 3, No. 11, 385-388. 


\section{APEM}

Advances in Production Engineering \& Management Letnik 16 | Številka 3 | September 2021 | Strani 307-325 https://doi.org/10.14743/apem2021.3.402
ISSN 1854-6250

Spletna stran: apem-journal.org Izvirni znanstveni članek

\title{
Povečanje ravni sigma pri izboljšanju produktivnosti in industrijske trajnosti z metodami šest sigma v proizvodni industriji: Sistematični pregled literature
}

\author{
Purba, H.H. ${ }^{a}$, Nindiani, A. ${ }^{b,}{ }^{,}$, Trimarjoko, A. ${ }^{a}$, Jaqin, C. ${ }^{a}$, Hasibuan, S. ${ }^{a}$, Tampubolon, S. ${ }^{a}$ \\ aDepartment of Industrial Engineering, Mercu Buana University, Jakarta, Indonesia \\ bIndustrial Engineering Program, Buana Perjuangan University, Karawang, Indonesia
}

\begin{abstract}
POVZETEK
Industrijska trajnost je pomemben atribut in parameter poslovnega uspeha. Izboljšanje kakovosti s povečanjem kazalnika zmogljivosti procesa bo vplivalo na izboljšanje produktivnosti in vodilo do industrijske konkurenčnosti ter ohranilo industrijsko trajnost. Namen tega prispevka je pridobiti razmerje med doslednostjo izvedbe faze DMAIC za povečanje ravni sigma in izboljšanjem produktivnosti in industrijske trajnosti. Ta članek je osnovan na sistematičnem pregledu literature iz različnih virov in zaupanja vrednih člankov od leta 2006 do 2019 z uporabo ključnih besed: šest sigma, produktivnost in industrijska trajnost. Za sintezo in povzetek literature smo uporabili poseben matrični pregled. Pristop šest sigma je bil uspešen pri zmanjševanju variacij izdelkov, napak, časa cikla, proizvodnih stroškov, pa tudi pri povečanju zadovoljstva strank, zmanjšanju stroškov, povečanju dobička in konkurenčnosti za ohranitev industrijske trajnosti. Z ekstrakcijo in sintezo so bile $v$ tej študiji pridobljene vrednosti sedmih ciljev, ki so razkrile dosledno razmerje med fazo DMAIC za povečanje ravni sigma, produktivnostjo in industrijsko trajnostjo. Velik obseg literature o šest sigma je zelo koristen za organizacije in jim pomaga razumeti kritične spremenljivke in ključne dejavnike uspeha pri izvajanju šest sigma, kar vodi do znatnih dolgoročnih nenehnih izboljšav, vrednosti denarja in poslovanja.
\end{abstract}

PODATKI O ČLANKU

Ključne besede: Proizvodnja;

Trajnost; Industrijska trajnost;

Šest sigma;

Povečanje ravni sigma;

Izboljšanje produktivnosti;

Industrijska konkurenčnost

*Kontaktna oseba:

aina.nindiani@gmail.com

(Nindiani, A.)

Zgodovina članka:

Prejet 30. julija 2020

Popravljen 24. oktobra 2021

Sprejet 26. oktobra 2021

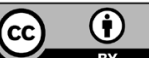

Content from this work may be used under the terms o the Creative Commons Attribution 4.0 International Licence (CC BY 4.0). Any further distribution of this work must maintain attribution to the author(s) and the title of the work, journal citation and DOI. 